\title{
Amelioration of human lupus-like phenotypes in MRL/Ipr mice by overexpression of interleukin 27 receptor $\alpha$ (WSX-1)
}

\author{
N Sugiyama, ${ }^{1}$ H Nakashima,,${ }^{1,2}$ T Yoshimura, ${ }^{3,4}$ A Sadanaga, ${ }^{1}$ S Shimizu, ${ }^{1} \mathrm{~K}$ Masutani, ${ }^{5}$ \\ T Igawa, ${ }^{1}$ M Akahoshi, ${ }^{1}$ K Miyake, ${ }^{1,2}$ A Takeda, ${ }^{3,4}$ A Yoshimura, ${ }^{4}$ S Hamano, ${ }^{6} \mathrm{H}$ Yoshida
}

\begin{abstract}
${ }^{1}$ Department of Medicine and Biosystemic Science, Graduate School of Medical Sciences, Kyushu University, Fukuoka, Japan; ${ }^{2}$ Division of Nephrology and Rheumatology, Department of Internal Medicine, Fukuoka University, School of Medicine, Fukuoka, Japan; ${ }^{3}$ Department of Ophthalmology, Graduate School of Medical Sciences, Kyushu University, Fukuoka, Japan; ${ }^{4}$ Division of Molecular and Cellular Immunology, Medical Institute of Bioregulation, Kyushu University, Fukuoka, Japan; ${ }^{5}$ Department of Medicine and Clinical Science, Graduate School of Medical Sciences, Kyushu University, Fukuoka, Japan; ${ }^{6}$ Department of Parasitology, Graduate School of Medical Sciences, Kyushu University, Fukuoka, Japan; 7 Department of Biomolecular Sciences, Faculty of Medicine, Saga University, Saga, Japan
\end{abstract}

Correspondence to: $\mathrm{H}$ Nakashima, Division of Nephrology and Rheumatology, Department of Internal Medicine, Fukuoka University, School of Medicine, 7-45-1 Nanakuma, Jonann-ku, Fukuoka 814-0180, Japan; hnakashi@ fukuoka-u.ac.jp and H Yoshida, Department of Biomolecular Sciences, Faculty of Medicine, Saga University, Saga, 849-8501, Japan yoshidah@med.saga-u.ac.jp

Accepted 30 November 2007 Published Online First

18 December 2007

\section{ABSTRACT}

Objective: In the present work, we investigate the role of interleukin (IL)27/IL27 receptor $\alpha(\mathrm{R} \alpha)$ (WSX-1) in the development of autoimmune disorders in the MRL/lpr mouse, which is considered as an experimental model of systemic lupus erythaematosus (SLE) in humans.

Methods: We generated two strains of WSX-1 transgenic mice in the MRL/lpr background with different expression levels of WSX-1, and investigated the effect of WSX-1 overexpression on survival, glomerulonephritis and immunological properties.

Results: In comparison with wild type (WT) MRL//pr and transgenic (Tg) low (TgL) mice, $\mathrm{Tg}$ high ( $\mathrm{TgH}$ ) mice exhibited a prolonged lifespan and no apparent development of autoimmune nephritis. Production of anti-dsDNA antibody and total $\lg \mathrm{G}$ and $\lg \mathrm{G} 2 \mathrm{a}$ were significantly lower in $\mathrm{TgH}$ mice than those of $\mathrm{TgL}$ and WT mice. The expressed amounts of interferon (IFN) $\gamma$ and IL4 mRNA by $\mathrm{CD}^{+} \mathrm{T}$ cells from $\mathrm{Tg}$ mice decreased in a dose-dependent fashion. $\mathrm{CD}^{+}$splenic lymphocytes in $\mathrm{TgH}$ mice were more subject to the IL27-mediated suppression of cytokine production. In vitro stimulation of $\mathrm{CD}^{+} \mathrm{T}$ cells by IL27 resulted in over phosphorylation of STAT3 in $\mathrm{TgH}$ cells than in WT cells.

Conclusion: WSX-1 overexpression in the MRL/lpr background rendered the autoimmune prone mice protected from the development of autoimmune diseases. Our results suggest that IL27 signalling may be a therapeutic target against autoimmune diseases, including human SLE.

Interleukin 27 is a member of the IL6/IL12 family and is composed of a p28 subunit and Epstein-Barr virus-induced gene 3 , polypeptides structurally related to p35 and p40 of IL12, respectively. ${ }^{1}$ IL27 is produced by activated antigen-presenting cells and induces proliferation of and $\mathrm{T}$ bet expression in naïve $\mathrm{CD}^{+} \mathrm{T}$ cells. ${ }^{2}$ WSX-1, which was cloned as a homologue of gp130 of the IL6 receptor, ${ }^{3}$ constitutes a functional signal-transducting receptor for IL27 with gp130. ${ }^{4}$ WSX-1 is highly expressed in CD4+ T cells as well as in natural killer (NK)/natural killer T (NKT) cells and macrophages. ${ }^{5} 6$ Analysis of mice deficient for WSX-1 infected with Leishmania major revealed the critical role of WSX-1 in the initial mounting of proper Th1 responses. ${ }^{6}$ In infection with Trichuris muris, a nematode whose clearance depends on Th2 responses, WSX-1-deficient mice showed impaired Th1 responses with augmented Th2 responses resulting in more efficient expulsion of the worms than that in wild type (WT) mice, confirming its role for Th1 development. ${ }^{7}$
Recent lines of evidence, however, have shown a distinct role for WSX-1 and its ligand, IL27, as an attenuator of inflammatory responses. In Toxoplasma gondii or Trypanosoma cruzi infection, CD4 ${ }^{+} \mathrm{T}$ cells as well as NKT cells and macrophages in WSX-1-deficient mice overproduced several inflammatory cytokines, resulting in devastating inflammation in the liver and other organs. ${ }^{9}{ }^{10}$ The suppressive role of WSX-1 was also observed in various experimental settings such as concanavalin A (Con A)-induced hepatitis, Mycobacterium tuberculosis infection, an allergic asthma model and experimental autoimmune encephalomyelitis. ${ }^{11-15}$ These data clearly demonstrated that IL27/WSX-1 plays an inhibitory role by regulating cell activation and cytokine production. ${ }^{16}$

Systemic lupus erythaematosus (SLE) is a multisystem disease that is caused by tissue damage resulting from autoantibody and complementfixing immune complex deposition. Lupus nephritis manifests considerable heterogeneity in phenotype and histology. In particular, diffuse proliferative glomerulonephritis (DPGN) and membranous glomerulonephritis (MGN) represent two histological forms that are polar opposites. ${ }^{17}{ }^{18}$ The pathogenesis of DPGN is associated with predominance of Th1 cytokines, ${ }^{19}$ while that of MGN with predominantly Th2 cytokine response. ${ }^{20} \mathrm{MRL} / \mathrm{lpr}$ mice develop a systemic autoimmune disease, which is reminiscent of SLE in humans. In MRL/ Ipr mice, Fas-mediated apoptosis of activated lymphocytes was severely impaired, and $\mathrm{T}$ celldependent production of autoantibodies results in immune complex-mediated glomerulonephritis and vasculitis. ${ }^{2122}$ Kidney disease in MRL/lpr mouse is a particularly suitable model of DPGN. Intriguingly, disruption of the WSX-1 gene changed the pathophysiology of glomerulonephritis developing in MRL/lpr (WT) mice. WSX-1-1 $\mathrm{MRL} /$ lpr mice developed a disease resembling human MGN with augmented Th2 responses, confirming that the Th1/Th2 cytokine balance is a key to the pathogenesis of differential types of glomerulonephritis. ${ }^{23}$ In this study, we generated lines of WSX-1 transgenic MRL/lpr mice to further investigate roles of IL27/WSX-1 in the development of autoimmune disorders in MRL/lpr mice.

\section{METHODS}

\section{Generation of WSX-1 transgenic MRL/Ipr mice}

WSX-1 transgenic mice in the MRL/lpr background were produced by crossing WSX-1 transgenic $\mathrm{BALB} / \mathrm{c}$ mice $^{24}$ into the MRL/lpr background more 
Table 1 Clinical manifestations and serum chemistry in female wild type (WT), transgenic low (TgL) and high $(\mathrm{TgH})$ mice

\begin{tabular}{lccc}
\hline & MRL/lpr 24W & \\
\cline { 2 - 4 } & WT & TgL & TgH \\
\hline Body weight, g & $49.0(6.10)$ & $43.1(4.40)$ & $40.4(3.00)$ \\
Spleen weight, g & $1.31(0.56)$ & $0.90(0.21)$ & $0.33(0.07)^{*}$ \\
Total lymph node weight, g & $6.14(1.71)$ & $3.43(3.31)$ & $1.51(0.53)^{*}$ \\
Urinary protein:creatinine ratio & $17.4(5.80)$ & $15.98(10.6)$ & $5.24(2.22)^{*}$ \\
Serum protein, g/dl & $6.83(0.67)$ & $6.93(0.66)$ & $7.68(0.77)$ \\
Blood urea nitrogen, mg/dl & $57.2(24.9)$ & $57.9(19.2)$ & $28.4(6.00)^{*}$ \\
Serum creatinine, mg/dl & $0.27(0.12)$ & $0.20(0.09)$ & $0.36(0.14)$ \\
\hline
\end{tabular}

Values are mean (SD).

${ }^{*} p<0.05$ vs WT

than six times (continual backcrossing: $98.44 \%$ in MRL/lpr background). Genotyping for $\mathrm{lpr}$ alleles was performed by PCR as described previously. ${ }^{23}$ We generated two strains of WSX-1 transgenic mice in the MRL/lpr background (transgenic high $(\mathrm{TgH})$ and low $(\mathrm{TgL}))$ depending on different expression levels of WSX-1. Female mice from the same litters were used in the present study. Mice were maintained in the Laboratory of Animal Experiments of Kyushu University. All experiments were approved by the Institutional Animal Research Committee of Kyushu University and conformed to the animal care guidelines of the American Physiologic Society.

\section{Western blotting}

We evaluated the production of WSX-1 protein in the transgenic mice using anti-T cell lymphocyte cytokine receptor (TCCR) (WSX-1) antibody (Abcam, Cambridge, Massachusetts, USA), anti- $\beta$-actin antibody (Sigma, St Louis, Missouri, USA), and anti-mouse IgG-horseradish peroxidase (HRP) antibodies (Amersham Biosciences, Piscataway, New Jersey, USA). They were visualised with an electrochemical luminescence (ECL) detection system (Amersham Biosciences).

\section{Laboratory assessments}

For serum chemistry, total protein, blood urea nitrogen (BUN) and creatinine $(\mathrm{Cr})^{8}$ levels were assessed in the sera from 10 mice in each group at 24 weeks. Urinary protein:urinary $\mathrm{Cr}$ ratios were also determined. Anti-nuclear antibodies (ANA) were detected by indirect immunofluorescence using HEp-2 substrate slides (Orgentec, Mainz, Germany) with fluorescein isothiocyanateconjugated AffiniPure donkey anti-mouse IgG (Jackson ImmunoResearch, West Grove, Pennsylvania, USA). ${ }^{25}{ }^{26}$ Serum anti-double-stranded DNA (anti-dsDNA) antibodies (Abs) were analysed by ELISA (Shibayagi, Gunma, Japan). For serum Ig, determination ELISA was performed using the following antibodies: rat anti-mouse IgG1 (Zymed Laboratories, San Francisco, California, USA), rat anti-mouse IgG1-HRP (BioSource International, Camarillo, California, USA), goat anti-mouse IgG2a (Bethyl Laboratories, Montgomery, Alabama, USA), rabbit anti-mouse IgG2a-HRP (Cappel Lab, Durham, North Carolina, USA) and goat anti-mouse IgE Ab (Bethyl Laboratories).

\section{Histopathological and immunohistopathological studies of kidneys}

The severity of glomerulonephritis was evaluated as described previously. ${ }^{23}$ For immunohistochemical staining, kidneys were snap frozen in optimal cutting temperature compound (Sakura, Osaka, Japan). To detect immune complex (IC) deposits, cryostat sections $(2 \mu \mathrm{m})$ were fixed in chilled acetone and stained with fluorescein isothiocyanate (FITC)-conjugated goat polyclonal anti-mouse IgG Abs (Organon Teknika, Scarborough, Maine, USA), a FITC-conjugated goat anti-mouse IgG1 $\mathrm{Ab}$ and a FITC-conjugated goat anti-mouse IgG2a $\mathrm{Ab}$ (Southern Biotechnology Associates, Birmingham, Alabama, USA). For negative controls, sections were treated with normal goat IgG (Santa Cruz Biotechnology, Santa Cruz, California, USA). The fluorescence strength was analysed using scion image (Scion Cooperation, Frederick, Maryland, USA). ${ }^{27}$
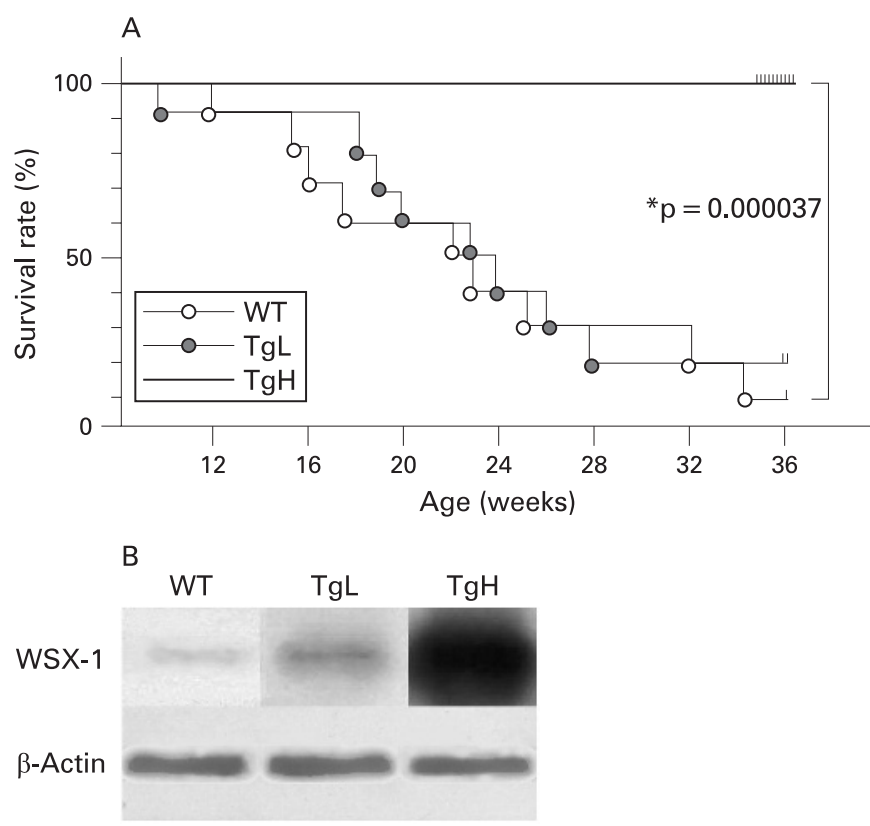

Figure 1 Prolonged survival of MRL/lpr mice with high expression of WSX-1. A. The cumulative survivals of wild type (WT), transgenic low $(\mathrm{TgL})$ and high $(\mathrm{TgH})$ mice were monitored weekly ( $n=20$ per group). ${ }^{*} p<0.05$ by the Kaplan-Meier method. There was no difference in the survival rate between WT and TgL mice. B. Western blot analysis of the transgenic expression of WSX-1 in CD4 ${ }^{+} \mathrm{T}$ cells from WT mice and two $\mathrm{Tg}$-positive MRL/lpr mouse lines, $\mathrm{TgL}$ and $\mathrm{TgH}$. The lysates of purified splenic $\mathrm{CD4}^{+} \mathrm{T}$ cells from 16-week-old WT, $\mathrm{TgL}$ and $\mathrm{TgH}$ mice were separated by sodium dodecyl sulfate polyacrylamide gel electrophoresis (SDS-PAGE) under reducing condition and transferred to membranes. Expression levels for $\beta$-actin protein was visualised for each sample as a loading control. The transgene products demonstrate robust, moderate and faint expression of WSX-1 in TgH, TgL and WT mice T cells, respectively. 


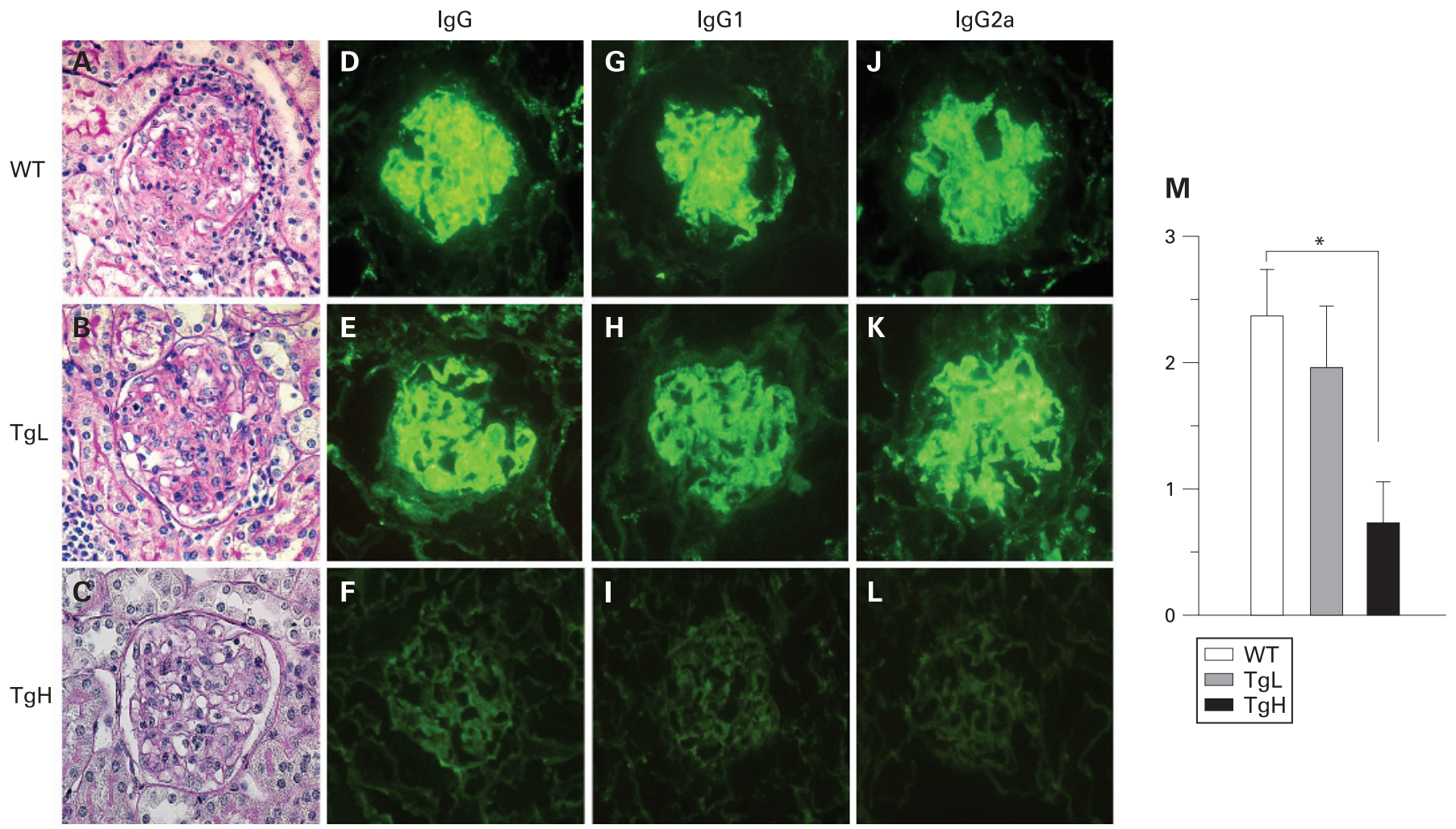

Figure 2 Amelioration of glomerulonephritis and decreased Ig deposition in transgenic high (TgH) mice. The kidneys were fixed in $10 \%$ formalin for 24 $\mathrm{h}$ at $4^{\circ} \mathrm{C}$. Paraffin sections $(4 \mu \mathrm{m})$ were stained either with H\&E, periodic acid Schiff stain, or periodic acid-methenamine silver (PAM). Microscopic examination of the kidney glomerulus of a 24-week-old wild type (WT) mouse (A), transgenic low (TgL) mouse (B) and TgH mouse (C) (periodic acid Schiff staining; original magnification, $\times 400)$. IgG $(\mathrm{D}, \mathrm{E}$ and $\mathrm{F}), \lg \mathrm{G} 1(\mathrm{G}, \mathrm{H}$ and I) and $\operatorname{lgG} 2 \mathrm{a}(\mathrm{J}, \mathrm{K}$ and $\mathrm{L})$ deposits in the glomeruli of a 24-week-old WT, $\mathrm{TgL}$ and $\mathrm{TgH}$ mice were visualised using immunofluorescent anti-lg staining $(\times 400)$ and quantitative analysed by image software. WT: IgG $(83.8$ (7.25)), IgG1 (68.4 (6.4)) and IgG2a (76.8 (4.9)), TgL: IgG (81.0 (8.48)), IgG1 (71.4 (7.3)) and IgG2a (73.0 (4.6)), TgH:IgG (25.2 (9.65)), IgG1 (22.8 (6.45)), IgG2a (19.6 (3.2)). These representative data obtained from 30 glomerular cross sections per kidney (six mice per group) with similar staining patterns. M. The severity of glomerulonephritis was evaluated by the score of glomerular proliferative activity. The scores of glomerular proliferative activity of 24-week-old WT, TgL and TgH mice were $2.38(0.356), 1.92(0.564)$ and $0.74(0.378)$, respectively.

\section{Real-time quantitative PCR and TaqMan primers and probes} Expression levels of interferon (IFN) $\gamma$ and IL4 in CD4 ${ }^{+} \mathrm{T}$ cells were determined using TaqMan PCR and an ABI prism 7700 sequence detection system (Applied Biosystems Japan, Tokyo, Japan). The relative expression of each mRNA was determined and normalised to the expression of the internal housekeeping gene glyceraldehyde 3-phosphate dehydrogenase (GAPDH). Primer and probe sequences are described previously. ${ }^{23}$

\section{Activation of $\mathrm{CD}^{+} \mathrm{T}$ cells}

$\mathrm{CD}^{+} \mathrm{T}$ cells were purified from splenic extracts using magnetic beads (Miltenyi Biotec $\mathrm{GmbH}$, Bergisch Gladbach, Germany). Purified $\mathrm{CD}^{+} \mathrm{T}$ cells were activated with plate-bound anti-CD3 $\mathrm{Ab}(1 \mu \mathrm{g} / \mathrm{ml})$ plus soluble anti-CD28 Ab $(1 \mu \mathrm{g} / \mathrm{ml})$ (BD Biosciences, San Jose, California, USA) for 2 days, transferred to a new plate without antibodies and additionally cultured for 5 days as a total of 7 days either in the presence or absence of IL27. Culture supernatants containing recombinant murine IL27 were prepared as described previously. ${ }^{16}$ The cells were then washed and restimulated either with anti-CD3 Ab plus antiCD28 Ab for cytokine production or with IL27 for signal transducer and activator of transcription (STAT) activation. Anti-STAT1, anti-phosphotyrosine (pY)-STAT1 and anti-pYSTAT3 Abs were purchased from New England BioLabs (Beverly, Massachusetts, USA). Anti-STAT3 Ab was purchased from Santa Cruz Biotechnology.

\section{Measurement of cytokines}

Cytokines in culture supernatants of CD4+ $\mathrm{T}$ cells were analysed using a micro bead-based ELISA system (Multiplex Antibody Bead Kits, Biosource) according to the manufacturer's directions with Luminex 100 (Luminex, Austin, Texas, USA). Cytokines in the sera were measured by ELISA kits (Genzyme, R\&D Systems, Abingdon, UK and eBioscience, Los Angeles, California, USA) for detection of IFN $\gamma$, IL4, IL17A and IL2.

\section{Statistical analyses}

For survival of mice, Kaplan-Meier analysis was carried out using the Statview software package (SAS Institute Japan, Tokyo, Japan). Other quantitative data were expressed as the mean (SD). The Mann-Whitney $U$ rank sum test was performed to analyse the difference between two groups, while for individual comparisons among the three groups the KruskalWallis test, followed by the Scheffe test was performed. All tests were two-tailed. A p value of less than 0.05 was considered statistically significant.

\section{RESULTS}

\section{Prolonged survival in $\mathrm{TgH}$ mice, not in $\mathrm{TgL}$ mice}

The MRL/lpr mice develop a rapid and fluminant autoimmune nephritis with $50 \%$ mortality at 6 months of age. ${ }^{28}$ In this study MRL/lpr mice (WT mice) died after birth at a rate described above. Although TgL mice died at the similar rate as WT mice, 


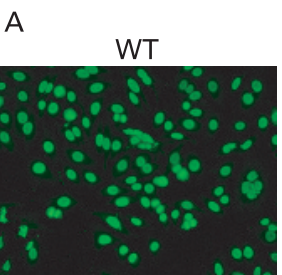

$\operatorname{TgL}$

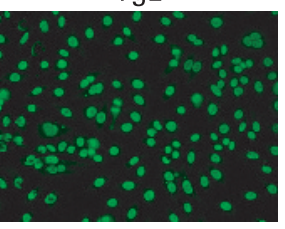

$\mathrm{TgH}$
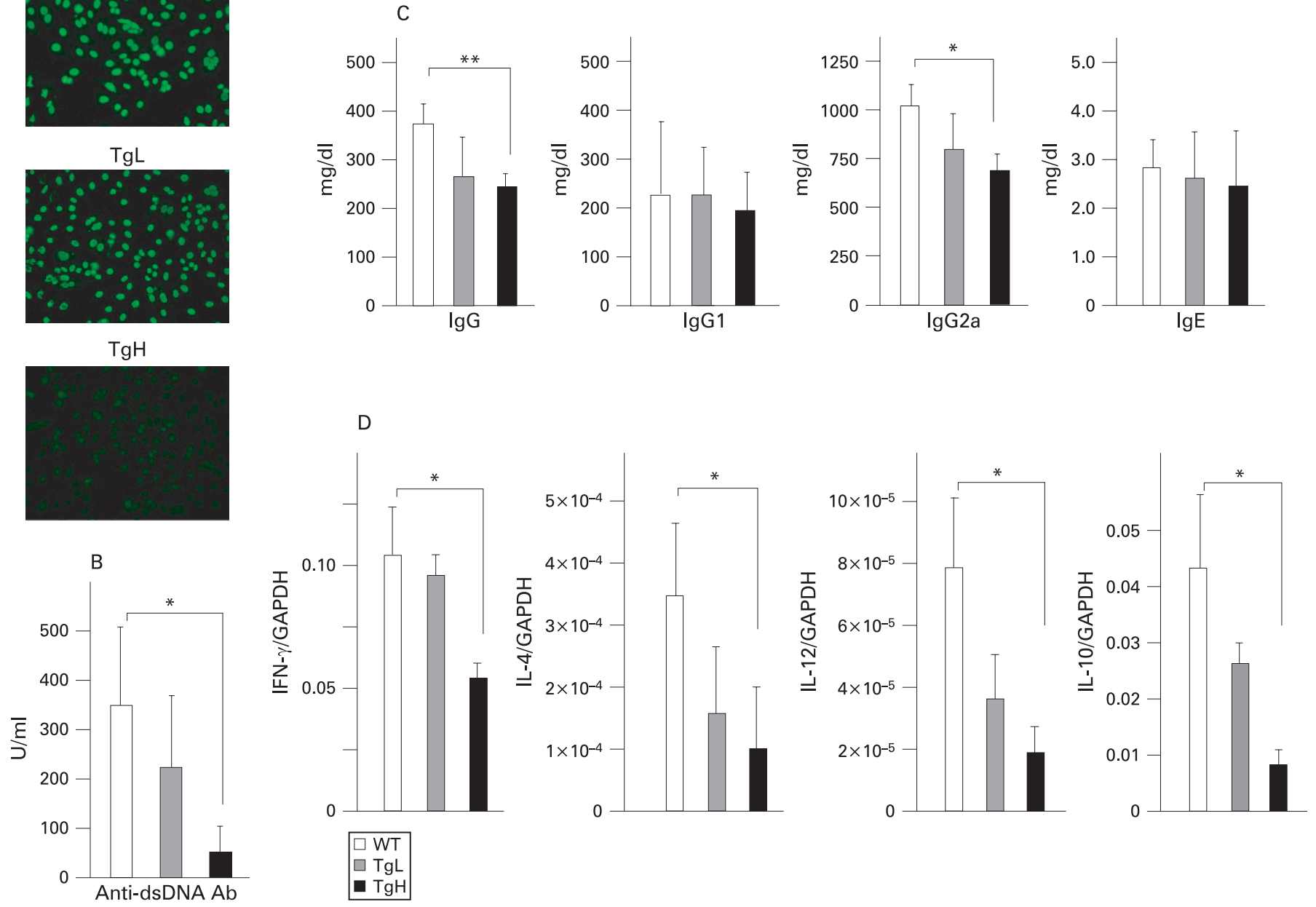

Figure 3 Decreased autoreactive immune responses in transgenic high (TgH) mice. A. Sera collected from 16-week-old wild type (WT), transgenic low (TgL) and TgH mice were examined for anti-nuclear antibodies (ANA) as described in Materials and methods. The same sera in (A) were measured for anti-dsDNA antibodies (B) or for Ig levels (C). D. The expression levels of interferon (IFN) $\gamma$ and interleukin (IL) 4 mRNA in CD4 ${ }^{+}$T cells and those of IL12 and IL10 mRNA in B220 ${ }^{+} \mathrm{CD}^{+}$cell-depleted splenocytes were examined by quantitative PCR. Data shown are mean (SD) of 10 mice per group. ${ }^{*} \mathrm{p}<0.05$ by unpaired Student $\mathrm{t}$ test.

$\mathrm{TgH}$ mice showed significantly extended survival rates $(0 \%$ dead at 24 weeks after birth; $\mathrm{p}<0.001$ over WT mice) (fig 1A).

\section{Improvement of clinical features and parameters in $\mathrm{TgH}$ mice}

Given the striking improvement of survival in $\mathrm{TgH}$ mice, clinical features and serum chemistry parameters of 24-week-old mice were examined. $\mathrm{TgH}$ mice showed significantly lower BUN, compared with WT and TgL mice (table 1). Additionally, the urinary protein:creatinine ratio was also lower in $\mathrm{TgH}$ mice than in TgL or WT mice. These data indicated amelioration of kidney function in $\mathrm{TgH}$ mice. The parameters of 36-week-old $\mathrm{TgH}$ mice were comparable with those of 24-week-old $\mathrm{TgH}$ mice (data not shown). Of note, splenomegaly and lymphadenopathy were also significantly reduced in $\mathrm{TgH}$ mice.

\section{Amelioration of glomerulonephritis in $\mathrm{TgH}$ mice}

Since kidney dysfunction is the primary cause of death in MRL/lpr mice, histopathological examination of kidneys from the three groups of 24-week-old mice was performed. Typical histological features of DPGN were observed in WT and also in TgL mice, including inflammatory cell infiltration, glomerular sclerosis, mesangial proliferation and crescent formation (fig 2A,B). By striking contrast, $\mathrm{TgH}$ mice showed drastic attenuation of inflammatory and proliferative changes (fig 2C). The score of glomerular proliferative activity of $\mathrm{TgH}$ was significantly decreased compared to that of WT (fig 2M. $p=0.0074 \mathrm{TgH}$ vs WT).

Deposition of immunoglobulin is one of the hallmarks of glomerulonephritis. ${ }^{15}$ We then performed immunofluorescent staining of the kidneys to detect Ig in glomeruli in the three groups of mice. An intense IgG deposition was detected in mesangial lesions and along the capillary walls of glomeruli in WT and TgL mice. The isotypes of the deposited Ig were mainly IgG2a and IgG1 in part (fig 2D,E,G,H,J,K). By contrast, IgG deposition was hardly observed in $\mathrm{TgH}$ mice, and the deposition of IgG1 and IgG2a was remarkably decreased (fig 2F,I,L), and the fluorescent strength score was significantly decreased ( $p=0.0035 \mathrm{TgH}$ vs WT).

\section{Decreased production of ANA, anti-dsDNA antibodies and immunoglobulins}

To further examine the immunological changes in $\mathrm{TgH}$ mice, the level and the nature of serum Ig and autoantibodies were 
Figure 4 Decrease in $\mathrm{CD}^{+}{ }^{+} \mathrm{B} 22 \mathrm{O}^{+} \mathrm{CD}^{-}{ }^{-} \mathrm{CD} 8^{-} \mathrm{T}$ cell and upregulated expression of activation markers on transgenic high $(\mathrm{TgH}) \mathrm{CD}^{+} \mathrm{T}$ cells. A. Spleens were removed from 16week-old wild type (WT) and $\mathrm{TgH}$ mice, and single cell suspensions were stained for the expression of surface markers, followed by flow cytometry. Numbers are the percentage of $\mathrm{CD}^{+}{ }^{+} \mathrm{B} 22 \mathrm{O}^{+} \mathrm{CD} 4^{-} \mathrm{CD} 8$ $\mathrm{T}$ cells, $\mathrm{CD}^{+} \mathrm{T}$ cells and $\mathrm{CD} 4^{+} \mathrm{T}$ cells against total cell populations. B. Surface expression levels of CD69, CD25, CD62L and CD44 were analysed by flow cytometry. Numbers are the percentage of the total $\mathrm{CD}^{+} \mathrm{T}$ cells.
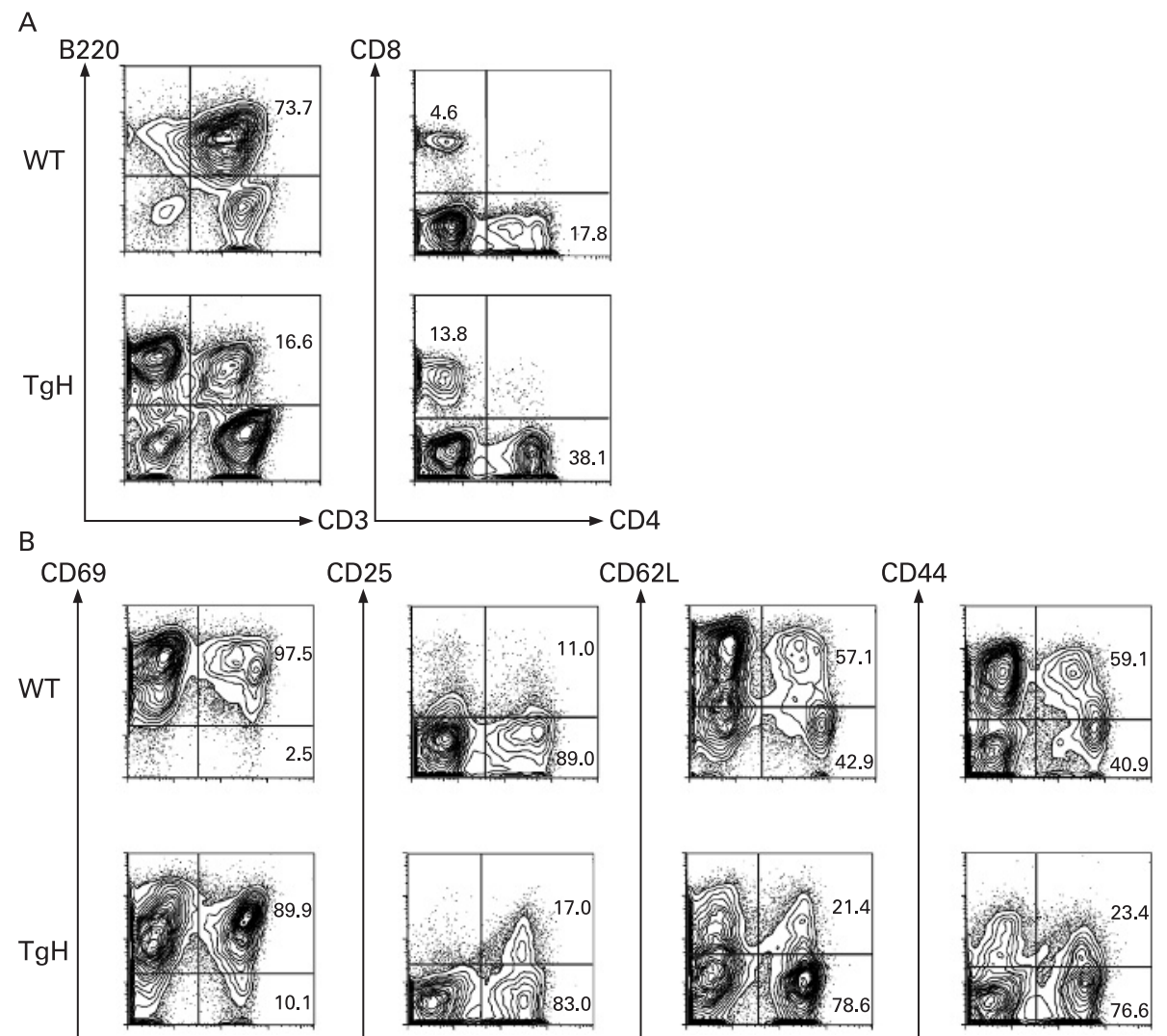

evaluated. Positive staining for ANA was detected in 16-weekold WT TgL mouse sera at a 1:200 dilution, as determined by indirect immunofluorescence ( $\mathrm{n}=10$ per group), whereas sera from 16-week-old TgH mice were negative for ANA $(n=8)$ (fig 3A). The sera from 24- and 36-week-old TgH mice were also negative (data not shown). Production of anti-dsDNA Abs was significantly lower in TgH mice than those of WT and TgL mice (fig $3 \mathrm{~B}$ ). While there were no significant differences in the levels of IgG1 and IgE, the levels of total IgG and IgG2a were significantly lower in $\mathrm{TgH}$ mice than in other groups (fig $3 \mathrm{C}$ ).

\section{Reduced cytokine production by $\mathrm{CD}^{+} \mathrm{T}$ cells from $\mathrm{TgH}$ mice}

Expression of IFN $\gamma$ and IL4 in splenic CD4 $4^{+} \mathrm{T}$ cells decreased in a manner dependent on the expression levels of WSX-1 (fig 3D). Similarly, expression of IL12b and IL10 in spleen cells depleted of $\mathrm{B}_{2} 2 \mathrm{O}^{+} \mathrm{CD}^{+}$cell was also decreased in WSX-1 transgenic mice.

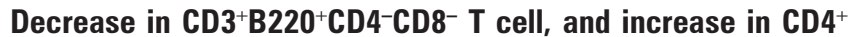 and $\mathrm{CD8}^{+} \mathrm{T}$ cell in the WSX-1 TgH MRL/Ipr mouse}

Given the significant improvement of splenomegaly and lymphadenopathy in $\mathrm{TgH}$ mice (table 1), cellular composition in the spleen was analysed. The percentage of $\mathrm{CD}^{+} \mathrm{B}_{22} \mathrm{O}^{+} \mathrm{CD}^{-} \mathrm{CD}^{-} \mathrm{T}$ cells in $\mathrm{TgH}$ mouse was greatly diminished over WT mice and in TgL mice (fig 4A, and data not shown). Concomitantly, percentages of $\mathrm{CD}^{+}$and $\mathrm{CD}^{+} \mathrm{T}$ cells increased compared with WT mice.

\section{Expression of activation markers in $\mathrm{CD}^{+} \mathrm{T}$ cells in WSX-1 $\mathrm{TgH}$ MRL/Ipr mice}

To clarify the activation status of $\mathrm{CD}^{+} \mathrm{T}$ cells in the mice, expression of several cell surface activation markers was evaluated (fig 4B). In WT and $\mathrm{TgH}$ mice, most of the $\mathrm{CD}^{+}$
T cells expressed CD69 on their cell surface, due presumably to in their possible autoreactivity. More than $10 \%$ of $\mathrm{CD}^{+} \mathrm{T}$ cells were positive for CD25 expression in WT and TgH mice. While some $40 \%$ of $\mathrm{CD}^{+} \mathrm{T}$ cells did not express CD62L in WT mice, approximately $80 \%$ of $\mathrm{CD}^{+} \mathrm{T}$ cells did not express CD62L. Interestingly, however, less $\mathrm{CD}^{+}{ }^{+} \mathrm{T}$ cells expressed CD44 in $\mathrm{TgH}$ mice than in WT mice. These data demonstrated that while most $\mathrm{CD}^{+} \mathrm{T}$ cells were activated by CD69 expression in WT and $\mathrm{TgH}$ mice, more cells in $\mathrm{TgH}$ mice showed the activated phenotype by CD62L expression. However, because much fewer cells expressed CD44 in TgH than in WT mice, the $\mathrm{CD}^{+} \mathrm{T}$ cells in $\mathrm{TgH}$ mice appeared to be in an activation status different from that in WT mice. Although the percentage of $\mathrm{CD}_{2} 5^{+}$cells in the $\mathrm{CD}^{+} \mathrm{T}$ cell population was higher in $\mathrm{TgH}$ mice than in WT mice, there was no significant difference in the expression levels of FoxP3 in $\mathrm{CD}^{+} \mathrm{T}$ cells between these mice (data not shown).

$\mathrm{CD4}^{+} \mathrm{T}$ cells from WSX-1 TgH mice were more subject to the IL27-mediated suppression of cytokine production

To examine the effect of IL27 on lymphocyte activity in the mice, cytokine production by in vitro activated $\mathrm{CD}^{+} \mathrm{T}$ cells either in the presence or absence of IL27 was examined (fig 4A). $\mathrm{CD}^{+} \mathrm{T}$ cells from $\mathrm{TgH}$ mice produced more IFN $\gamma$ and less IL4 than those from WT mice. Nonetheless, $\mathrm{CD}^{+}{ }^{+} \mathrm{T}$ cells from $\mathrm{TgH}$ mice were more sensitive to IL27-mediated suppression of cytokine production. Although WT and TgH CD4 ${ }^{+} \mathrm{T}$ cells were subject to IL27-mediated suppression of IFN $\gamma$ and IL4 production, the suppressive effect was prominent in TgH cells over WT cells. Production of IFN $\gamma$ and IL4 was strikingly suppressed to barely detectable levels in $\mathrm{TgH} \mathrm{CD}^{+} \mathrm{T}$ cells. IL17 production by TgH CD4 ${ }^{+} \mathrm{T}$ cells was lower than WT cells even without IL27 

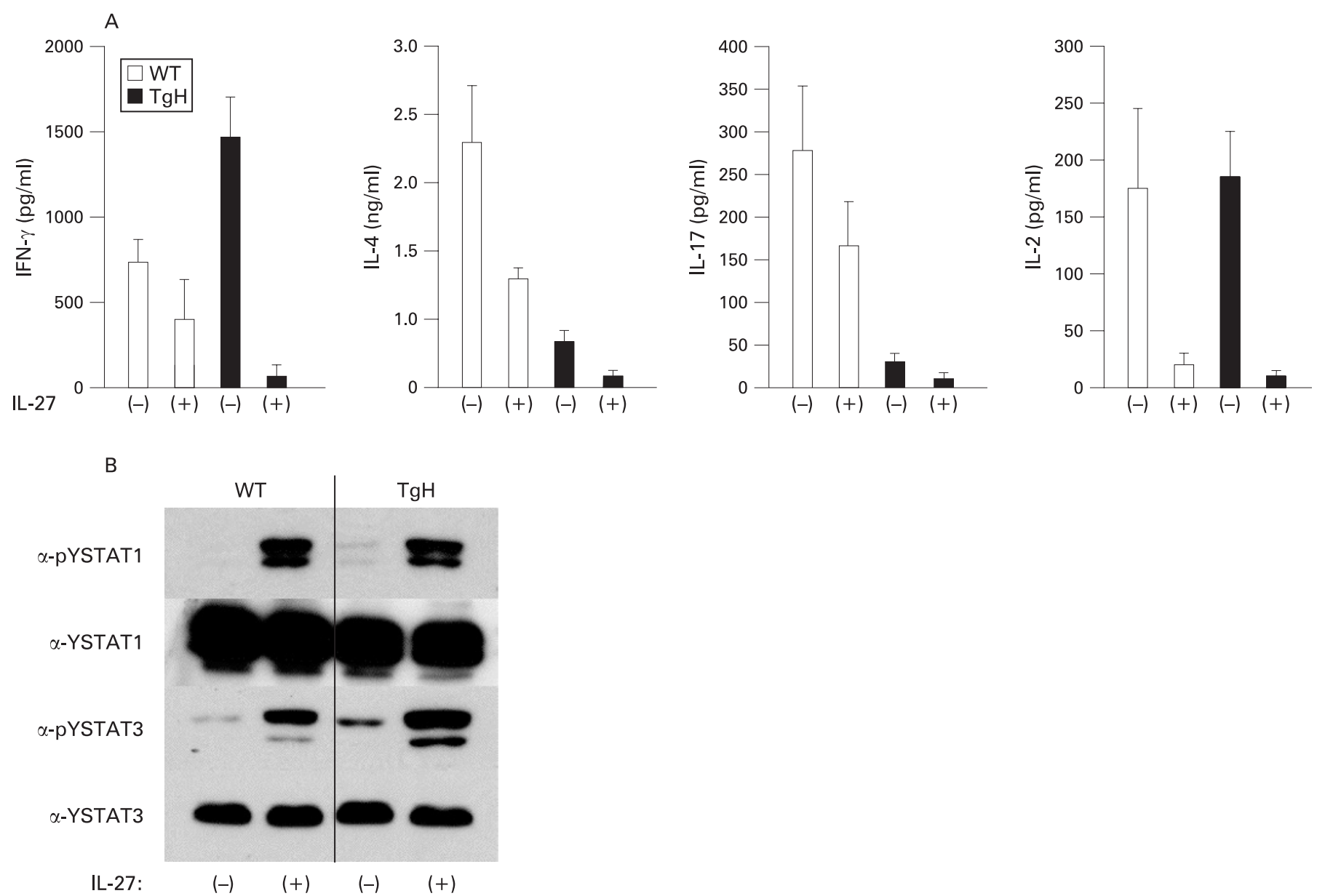

Figure 5 IL27 suppression of cytokine production by activated CD4 ${ }^{+}$T cells. A. CD4 ${ }^{+}$T cells from wildtype (WT) and transgenic high (TgH) mice were stimulated with plate-bound anti-CD3 antibody plus soluble anti-CD28 antibody (1 $\mu \mathrm{g} / \mathrm{ml})$ in the absence or presence of interleukin (IL)27 for $24 \mathrm{~h}$. Culture supernatants were measured for the production of respective cytokines. Data shown are mean (SD) of 10 mice per group. ${ }^{*} p<0.05$ by unpaired Student $t$ test. B. CD4 ${ }^{+}$T cells from WT and TgH mice were stimulated as in Materials and methods. Phosphorylation of signal transducer and activator of transcription (STAT)1 or STAT3 in whole cell lysates in WT and TgH mice was analysed with anti-phosphotyrosine ( $\alpha$-pY) -STAT1 or anti-pY-STAT3 antibodies, respectively. The filter was stripped and re-probed with anti-STAT1 or anti-STAT3 antibodies to ensure the same amounts of samples were loaded. Experiments were repeated three times with similar results.

addition, and was suppressed to a barely detectable level in TgH cells. Interestingly, IL2 production was not affected by WSX-1 overexpression and $\mathrm{CD}^{+}$cells from WT and $\mathrm{TgH}$ mice were similarly subject to IL27-mediated suppression.

Downstream of the IL27R (WSX-1 plus gp130), STAT1 and STAT3 are activated. ${ }^{16}{ }^{24}$ When $\mathrm{CD} 4^{+} \mathrm{T}$ cells were isolated and immediately examined for STAT1/3 phosphorylation, phosphorylation of STAT1 and STAT3 was apparent in TgH CD4 ${ }^{+}$ $\mathrm{T}$ cells as compared with WT cells (fig $5 \mathrm{~B}$ ). When these cells were stimulated with IL27 for $1 \mathrm{~h}$, further phosphorylation of STAT1 and STAT3 was observed in WT and Tg cells. While the levels of STAT1 phosphorylation were comparable between WT and $\mathrm{Tg}$ cells, STAT3 phosphorylation was higher in Tg cells than in WT cells.

\section{DISCUSSION}

In this study we generated lines of $\mathrm{Tg}$ mice that overexpressed WSX-1 in T cells to examine the impact of WSX-1 overexpression on pathophysiology and autoimmune status of MRL/lpr mice. We demonstrated that overexpression of WSX-1 suppressed the development of autoimmune nephritis in WT mice, and ANA, the values of anti-dsDNA Ab, serum Ig and expression of various cytokines, significantly decreased in of the Tg mice. While $\mathrm{CD}^{+} \mathrm{T}$ cells in $\mathrm{TgH}$ mice were in a distinct activation status from those in WT mice, these cells were more subject to the effects of IL27 in vitro. These results strongly suggested that increased expression of WSX-1 suppressed the autoimmune reaction and the subsequent glomerulonephritis in WT mice.

We originally demonstrated the pivotal role of WSX-1 in the initial mounting of Th1 differentiation via $\mathrm{T}$ bet induction, ${ }^{2}$ and in mice deficient in the WSX-1 gene, proper Th1 differentiation was impaired with Th2 skewing during protozoan infection. ${ }^{6}$ In line with these findings, we revealed that disruption of the WSX-1 gene drastically changed the histological features of glomerulonephritis developing in MRL/lpr mice from DPGN to MGN accompanied by impaired IFN $\gamma$ production with predominance Th2-dependent IgG1 deposition and increased levels of IgG1 and IgE in the sera. ${ }^{23} \mathrm{~T}$ cells in WSX-1/- MRL/lpr mice displayed spontaneous skewing of autoimmune responses toward Th2 type. Thus, our previous reports suggested that immune status, or more specifically, the balance between Th1 and Th2 responses, is a key determinant for the pathogenesis of the glomerulonephritis. Counterintutively, transgenic overexpression of WSX-1 gene resulted in amelioration of glomerulonephritis in MRL/lpr mice. It would be reasonable to assume 
this was the result of the suppressive effects of IL27 since the cytokine expression by $\mathrm{CD}^{+} \mathrm{T}$ cells as well as autoimmune reaction was suppressed in $\mathrm{TgH}$ mice.

$\mathrm{CD}^{+} \mathrm{T}$ cells from $\mathrm{TgH}$ mice activated in vitro produced more IFN $\gamma$ and less IL4 than those from WT mice and showed Th1 phenotyping, which was in line with the Th1-promoting function of IL27. However, IL27 addition strikingly suppressed production of IFN $\gamma$ and IL4 to barely detectable levels in $\mathrm{Tg}$ $\mathrm{CD}^{+} \mathrm{T}$ cells (fig $5 \mathrm{~A}$ ). These results confirmed the suppressive effect of IL27 on cytokine production and also revealed that the suppressive effect was much higher for $\mathrm{CD}^{+} \mathrm{T}$ cells of $\mathrm{TgH}$ than for those of WT mice. Such suppression of cellular response was largely consistent with the diminished pathophysiology of glomerulonephritis in $\mathrm{TgH}$ mice. We have recently reported that IL27 exerts its suppressive effects preferentially on activated $\mathrm{CD}^{+} \mathrm{T}$ cells, and that STAT3 activation in response to IL27 stimulation of activated T cells is, at least partially, responsible for the IL27-mediated suppression of cytokine production. ${ }^{16}$ This is quite consistent with our present finding that $\mathrm{TgH}$ mice $\mathrm{CD}^{+} \mathrm{T}$ cells were more sensitive to IL27 stimulation by STAT3 activation (fig 5B). Ohwaki et al reported the involvement of STAT1 in IL27-mediated suppression of IL2 production by naïve $\mathrm{T}$ cells, ${ }^{29}$ although Villarino et al reported that IL27-mediated suppression in activated T cells is independent of STAT1. ${ }^{30}$ The discrepancy may be ascribed to the activation status of the cells.

In summary, we demonstrated that WSX-1 overexpression in the MRL/lpr background rendered the autoimmune prone mice protected from the development of autoimmune disease. Further elucidation of the molecular mechanisms underlying the IL27-mediated cytokine suppression and detailed dissection of the situations where IL27 differentially exerts its two roles will no doubt help development of new therapies against various diseases by suppressing excess of cell responses.

Acknowledgements: The authors thank Ms H Noguchi and Ms Y Furukawa for their excellent technical assistance. We are grateful to Dr M Hanada for encouragement and support of our study.

Funding: This study was supported in part by grants from the Ministry of Education, Science, Technology, Sports and Culture of Japan (to AY, SH and HY), from Japan Research Foundation for Clinical Pharmacology (to HY), from the Sumitomo Foundation, Grant for Basic Science Research Projects (to HY), from the Naito Foundation (to HY), and from the Takeda Science Foundation (to HY). This work was also supported by the president's expenditure (research project expenditure) of Saga University (to HY)

Competing interests: None declared.

\section{REFERENCES}

1. Pflanz S, Timans JC, Cheung J, Rosales R, Kanzler H, Gilbert J, et al. IL-27, a heterodimeric cytokine composed of EBI3 and p28 protein, induces proliferation of naive CD4(+) T cells. Immunity 2002;16:779-90.

2. Takeda A, Hamano S, Yamanaka A, Hanada T, Ishibashi T, Mak TW, et al. Cutting edge: role of IL-27/WSX-1 signaling for induction of T-bet through activation of STAT1 during initial Th1 commitment. J Immunol 2003;170:4886-90.

3. Sprecher CA, Grant FJ, Baumgartner JW, Presnell SR, Schrader SK, Yamagiwa T, et al. Cloning and characterization of a novel class I cytokine receptor. Biochem Biophys Res Commun 1998;246:82-90.

4. Pflanz S, Hibbert L, Mattson J, Rosales R, Vaisberg E, Bazan JF, et al. WSX-1 and glycoprotein 130 constitute a signal-transducing receptor for IL-27. J Immunol 2004:172:2225-31.
5. Chen Q, Ghilardi N, Wang H, Baker T, Xie MH, Gurney A, et al. Development of Th1type immune responses requires the type I cytokine receptor TCCR. Nature 2000;407:916-20

6. Yoshida H, Hamano S, Senaldi G, Covey T, Faggioni R, Mu S, et al. WSX-1 is required for the initiation of Th1 responses and resistance to $L$. major infection. Immunity 2001;15:569-78.

7. Artis D, Villarino A, Silverman M, He W, Thornton EM, Mu S, et al. The IL-27 receptor (WSX-1) is an inhibitor of innate and adaptive elements of type 2 immunity. $\mathrm{J}$ Immunol 2004:173:5626-34.

8. Bancroft AJ, Humphreys NE, Worthington JJ, Yoshida H, Grencis RK. WSX-1: a key role in induction of chronic intestinal nematode infection. J Immunol 2004;172:7635-41.

9. Hamano S, Himeno K, Miyazaki Y, Ishii K, Yamanaka A, Takeda A, et al. WSX-1 is required for resistance to Trypanosoma cruzi infection by regulation of proinflammatory cytokine production. Immunity 2003;19:657-67.

10. Villarino A, Hibbert L, Lieberman L, Wilson E, Mak T, Yoshida H, et al. The IL-27R (WSX-1) is required to suppress $T$ cell hyperactivity during infection. Immunity 2003:19:645-55.

11. Yamanaka A, Hamano S, Miyazaki Y, Ishii K, Takeda A, Mak TW, et al. Hyperproduction of proinflammatory cytokines by WSX-1-deficient NKT cells in concanavalin A-induced hepatitis. J Immunol 2004;172:3590-6.

12. Holscher C, Holscher A, Ruckerl D, Yoshimoto T, Yoshida H, Mak T, et al. The IL-27 receptor chain WSX-1 differentially regulates antibacterial immunity and survival during experimental tuberculosis. J Immunol 2005;174:3534-44.

13. Miyazaki Y, Inoue $\mathrm{H}$, Matsumura M, Matsumoto $\mathrm{K}$, Nakano $\mathrm{T}$, Tsuda $\mathrm{M}$, et al. Exacerbation of experimental allergic asthma by augmented Th2 responses in WSX-1deficient mice. J Immunol 2005;175:2401-7.

14. Batten M, Li J, Yi S, Kljavin NM, Danilenko DM, Lucas S, et al. Interleukin 27 limits autoimmune encephalomyelitis by suppressing the development of interleukin 17producing T cells. Nature immunology 2006;7:929-36.

15. Stumhofer JS, Laurence A, Wilson EH, Huang E, Tato CM, Johnson LM, et al. Interleukin 27 negatively regulates the development of interleukin 17-producing $T$ helper cells during chronic inflammation of the central nervous system. Nature immunology 2006;7:937-45.

16. Yoshimura T, Takeda A, Hamano S, Miyazaki Y, Kinjyo I, Ishibashi T, et al. Two-sided roles of IL-27: induction of Th1 differentiation on naive CD4+ T cells versus suppression of proinflammatory cytokine production including IL-23-induced IL-17 on activated CD4+ T cells partially through STAT3-dependent mechanism. J Immunol 2006;177:5377-85

17. Dixon FJ. The pathogenesis of glomerulonephritis. Am J Med 1968:44:493-8.

18. Churg J, Bernstein J, Glassock RJ, eds. Renal disease: classification and atlas of glomerular disease. Tokyo, Japan: Igaku-Shoin, 1995:151-6.

19. Masutani K, Akahoshi M, Tsuruya K, Tokumoto M, Ninomiya T, Kohsaka T, et al. Predominance of Th1 immune response in diffuse proliferative lupus nephritis. Arthritis Rheum 2001:44:2097-106.

20. Akahoshi M, Nakashima H, Tanaka Y, Kohsaka T, Nagano S, Ohgami E, et al. Th1/ Th2 balance of peripheral T helper cells in systemic lupus erythematosus. Arthritis Rheum 1999;42:1644-8

21. Van Parijs L, Abbas AK. Role of Fas-mediated cell death in the regulation of immune responses. Curr Opin Immunol 1996:8:355-61.

22. Theofilopoulos AN, Dixon FJ. Murine models of systemic lupus erythematosus. $A d v$ Immunol 1985;37:269-390.

23. Shimizu S, Sugiyama N, Masutani K, Sadanaga A, Miyazaki Y, Inoue Y, et al. Membranous glomerulonephritis development with Th2-type immune deviations in MRL/Ipr mice deficient for IL-27 receptor (WSX-1). J Immunol 2005:175:7185-92.

24. Takeda A, Hamano S, Shiraishi H, Yoshimura T, Ogata H, Ishii K, et al. WSX-1 overexpression in $\mathrm{CD} 4(+) \mathrm{T}$ cells leads to hyperproliferation and cytokine hyperproduction in response to TCR stimulation. Int Immunol 2005;17:889-97.

25. Wu X, Peng SL. Toll-like receptor 9 signaling protects against murine lupus. Arthritis Rheum 2006;54:336-42.

26. Christensen SR, Kashgarian M, Alexopoulou L, Flavell RA, Akira S, Shlomchik MJ. Toll-like receptor 9 controls anti-DNA autoantibody production in murine lupus. J Exp Med 2005;202:321-31.

27. Hirakawa M, Tsuruya $K$, Yotsueda H, Tokumoto M, Ikeda $H$, Katafuchi R, et al Expression of synaptopodin and GLEPP1 as markers of steroid responsiveness in primary focal segmental glomerulosclerosis. Life Sci 2006;79:757-63.

28. Cohen PL, Eisenberg RA. Lpr and gld: single gene models of systemic autoimmunity and lymphoproliferative disease. Annu Rev Immunol 1991:9:243-69.

29. Owaki T, Asakawa M, Fukai F, Mizuguchi J, Yoshimoto T. IL-27 induces Th1 differentiation via p38 MAPK/T-bet- and intercellular adhesion molecule-1/LFA-1/ ERK1/2-dependent pathways. J Immunol 2006;177:7579-87.

30. Villarino AV, Stumhofer JS, Saris CJ, Kastelein RA, de Sauvage FJ, Hunter CA. IL-27 limits IL-2 production during Th1 differentiation. J Immunol 2006:176:237-47. 